JMKSP (Jurnal Manajemen, Kepemimpinan, dan Supervisi Pendidikan)

Volume 7 Issue 1 (2022) Page 98-109

ISSN 2614-8021 (Online) 2548-7094 (Print)

\title{
Implementation of Online Learning Management For Elementary School Students in Rural Times During The Covid-19 Pandemic
}

\author{
Luthfi Audia Pribadi ${ }^{1}$, Diding Nurdin ${ }^{1}$, Yayah Rahyasih ${ }^{1}$ \\ ${ }^{1}$ Universitas Pendidikan Indonesia \\ Corresponding Author E-mail: Luthfipribadi@upi.edu
}

Received 14 August 2021; Revised 20 December 2021; Accepted 9 January 2021

\begin{abstract}
The focus of research is on teachers as managers in managing online learning during the Covid-19 pandemic. This study uses a descriptive-qualitative approach, namely describing and revealing existing facts and then describing them descriptively with words or descriptions. The results of the study indicate that the application of management functions can minimize the impact of online learning in the village. The existence of innovative learning methods that are considered effective in teaching and learning activities. Troubleshooting the flow of communication between schools and parents. The research was conducted in a rural area, namely SDN Negla (Kertasari) Bandung Regency, West Java Province. What is new in this research is that it is carried out in rural areas where the majority of human resources have minimal technological knowledge.
\end{abstract}

Keyword: Management, Learning, Teacher, Online

\section{Introduction}

Education determines the development and realization of human resources, especially the development of the nation and state. Education has an important role in forming intelligent, capable, creative, faithful, and noble human resources. Primary school education is the initial education of children to develop knowledge (Muhroji et al., 2020) Due to the covid-19 pandemic, teachers are required to find a distance learning method/design as an effort to prevent the spread of the covid- 
19 virus. During the covid-19 pandemic, every school has carried out educational activities by means of distance learning.

Given that the problems caused by the Covid-19 pandemic, it demands to find a formula so that programs that are integrated into the learning system especially in rural areas can run optimally again, besides how to instill character education values, it is necessary to have management that includes functions management of strengthening character education starting from planning, organizing, implementing and controlling or evaluating it. Every citizen has the right to education because getting education is the right of citizens (UUD Indonesia, No 20 2003), Likewise for people in urban and rural areas, they all have the right to receive a proper education. Education as a learning process so that students can develop their potential actively. Likewise, with the people in the village. Rural communities also have the same opportunities as urban communities to obtain education. The government opens equal educational opportunities for rural and urban communities. In fact, the fighting spirit of the rural community is higher than that of the urban community. Because urban people think that education in the village is not so advanced because of the lack of adequate facilities and infrastructure. Because education in the village and in the city is very different. (Vito \& Krisnani, 2015).

Educational administration includes education management, one of which is managing education. As a social human being, we must communicate, socialize with each other and cooperate with each other to achieve their goals. In life, communication is an important thing that happens, in the context of education, namely learning, it is the key to success. There are 4 main functions that are steps in management activities. There are 4 roles of teachers as managers in the teaching process as follows. (1). Planning is compiling teaching and learning objectives (teaching). Planning is done by developing an annual plan, semester plan, part plan (subject) weekly plan and daily plan (lesson plan). Learning planning is a set of plans and arrangements for learning activities, learning media, time, class management, and learning assessment. The benefits of lesson planning are to facilitate the preparation of learning and facilitate the development of active, creative, effective and fun learning. (2). Organizing, namely connecting or combining all teaching and learning resources in achieving goals effectively and efficiently. (3). Leading, namely motivating students to be ready to receive the subject matter, (4). Supervise, namely whether the work or teaching and learning activities achieve the planned goals and in accordance with what is intended. The 
benefits of lesson planning are to facilitate the preparation of learning and facilitate the development of active, creative, effective and fun learning. (2). Organizing, namely connecting or combining all teaching and learning resources in achieving goals effectively and efficiently. (3). Leading, namely motivating students to be ready to receive the subject matter, (4). Supervise, namely whether the work or teaching and learning activities achieve the planned goals and in accordance with what is intended. The benefits of lesson planning are to facilitate the preparation of learning and facilitate the development of active, creative, effective and fun learning. (2). Organizing, namely connecting or combining all teaching and learning resources in achieving goals effectively and efficiently. (3). Leading, namely motivating students to be ready to receive the subject matter, (4). Supervise, namely whether the work or teaching and learning activities achieve the planned goals and in accordance with what is intended. namely motivating students to be ready to receive the subject matter, (4). Supervise, namely whether the work or teaching and learning activities achieve the planned goals and in accordance with what is intended. namely motivating students to be ready to receive the subject matter, (4). Supervise, namely whether the work or teaching and learning activities achieve the planned goals and in accordance with what is intended (Maria \& Sediyono, 2017) In line with the opinion above, Marjuni argues that Discussing the relationship of learning, learning interaction is strongly influenced by several components, namely: students, teachers, principals, curriculum, school facilities (libraries), and several other facilities needed in the learning process so that it will support the quality of learning. Thus, learning activities can bring changes to students, both changes in knowledge, behavior, and skills. With these changes, of course, students will be trained in solving life problems and be able to adapt to their environment (Marjuni \& Harun, 2019)

Students' e-learning attitudes are defined as students' impressions of the elearning program. things such as patience, self-discipline, time management, technical ability, and enthusiasm for e-learning are all highly correlated and greatly affect students' e-learning attitudes. This is in line with that stated by Adewole-Odeshi (2014) who found that a positive attitude towards e-learning affects student learning success. Students who are more proactive and positive about the use of information technology and computer literacy are more satisfied and productive when participating in e-learning programs (Piccoli et al., 2001). found that students' attitudes towards e-learning, including the use of computers 
and information technology, had a positive effect on their satisfaction with elearning.

Management in learning activities is a pattern of interaction and communication between teachers and students with the intention to acquire knowledge, attitudes, skills, or explore what is learned. (Maria \& Sediyono, 2017). In harmony with Viet in its educational journal, that in learning activities teachers must be able to manage learning, teachers as managers carry out various steps in activities ranging from planning, organizing, applying and evaluating the learning carried out. (Cavenett, 2013). Based on the journal above, it can be concluded that the concept of learning management can be understood as a process of managing which includes planning, organizing, actuating and evaluating the learning process related to all components in it in order to achieve goals. According to Ibrahim Bafadhal, learning management is all actions in order to achieve an educative, effective, efficient teaching and learning process

Covid-19 is a pandemic that is causing problems for the whole world right now. The impact that is felt especially in the world of education causes a decrease in the quality of learning in students. Indonesia is also inseparable from the impact of the Covid-19 virus. School activities from cities to villages stop face-to-face learning in exchange for online-based learning. The efforts made by the school during this emergency are expected to solve problems in teaching and learning activities. Lack of knowledge about this technology triggers the failure of effective learning implementation.

As the spearhead and the frontline during teaching and learning activities, educators must still be able to present active, innovative, creative, effective, fun and efficient learning, and contain transfer of knowledge and transfer of value values. Therefore, during the COVID-19 pandemic, the role of educators is very urgent in managing distance learning (PJJ) both online and offline. To ensure the quality of learning, educators as much as possible manage learning starting from planning (planning), organizing (organizing), implementation (actuating) and evaluation (evaluating). (Ainun, 2021).

Creating an interesting learning atmosphere is important at this time, where currently many choose to carry out face-to-face learning and this requires educators to have the skills to create interesting and fun learning. According to learning management is to achieve a pleasant learning atmosphere first by preparing learning tools, media, and evaluation tools that are in accordance with 
the current conditions of students. This evaluation aims to determine the success that has been achieved in learning. (Idhayani et al., 2020)

Government policy through Circular No. 4 of 2020, (Almaiah et al., 2020) Regarding the adaptation of new habits during the COVID-19 pandemic, this is a reference in policies that lead to changes in learning media. In rural areas, the application of an Internet-based learning system raises its own problems. One of the experiences experienced by the village of Neglawangi, Kertasaari sub-district, which became the research locus in the management of online learning in the midst of the lack of internet facilities and infrastructure. The online learning process or e-learning is considered very good for inhibiting the spread of the COVID-19 pandemic, which is implied in the government circular. This situation demands that schools and universities must be ready to undergo changes in the learning system. mostopha, et al (2019) say that online learning is a distance learning system that uses technology assistance. Online learning is learning without face to face directly between teachers and students, but it is done online either through video conferences, e-learning or distance learning. (Ainun, 2021).

The field of education administration is expected to provide solutions regarding effective and efficient learning management/management even though this pandemic period demands the role of school stakeholders to adapt. In the midst of a pandemic like today, learning methods are needed that can protect children from the risk of being infected but can still make learning activities as effective as before. (Mulyasidhi \& Haq, n.d.2020) According to WHO (World Health Organization), a situation can be said to be a pandemic if there is a disease that spreads massively and exceeds normal limits, the world of education is also affected. Starting from kindergarten to university are required to adjust the existing conditions. The development of science and technology is increasingly encouraging renewal efforts in order to adapt to environmental conditions and times. Therefore, with the current Covid-19 pandemic, it is necessary to renew learning methods, considering the possibility of contracting the disease is quite high if we make a crowd.

\section{Methods}

This study applies the principles of a qualitative descriptive approach. The informants in the study were: 3 teachers, 3 parents/guardians of students and 1 principal. Research informants were determined by purposive sampling. The study was conducted for 4 months, starting from May to August 2021. Secondary 
data sources were obtained from data available at schools, and other sources. To be able to obtain data holistically and integrative, the data collection in this study used three methods, namely: 1) Interview using an interview guide instrument; 2) Participant observation; and 3) Study documentation (study document). Analysis of research data using a single case analysis, namely: data reduction, presentation, and drawing conclusions; The stages of the research can be seen in Figure 1:

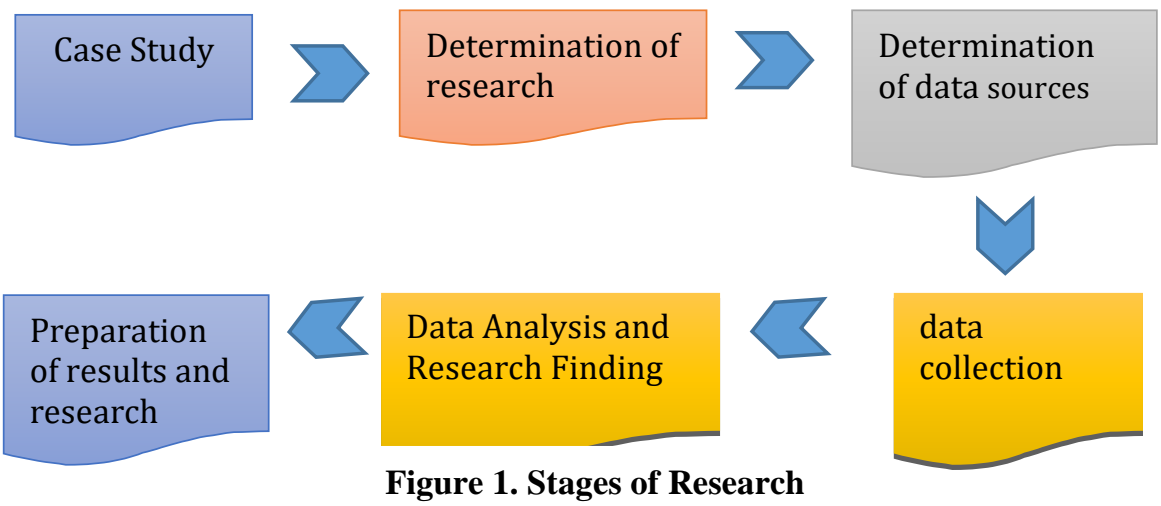

\section{Results and Discussion}

\section{Implementation of Online Learning Management at SDN Negla During the Covid-19 Pandemic}

In overcoming online learning at SDN Negla, one of them is using WhatsApp as a learning medium. The ways to use WhatsApp in learning are (1) the teacher creates a group together with parents; (2) every class hour the teacher asks the student's condition and ensures that the student stays at home, after that the teacher gives assignments to replace the learning process at school; (3) parents accompany and inform their children to do the tasks given by the teacher; (4) parents send documentation and proof of their child's work; (5) after that the teacher assesses using qualitative research. 


\section{Table 1. Observations at SDN Negla, Kertasari District}

In fact, interaction activities using the WhatsApp Group application describe interaction activities between teachers, students and parents. In the WA group, students can ask questions. Review material and also submit assignments. While Facebook messenger is used as a medium when the WA application is having problems.

Regarding

Media used

Learning process

How to assess

How to assist parents

\section{Observation Results}

In general, the media used in the online learning process at SDN Negla is utilizing the WhatsApp application, Facebook messenger, but not only digital media, the teacher also conducts offline classes in this case the teacher visits students' homes (Door to Door) to carry out teaching and learning activities.

In general, the learning process is only done by sending assignments through the WhatsApp Group WA application or sending it to the students' parents.

In this case the teacher uses motivation to students with positive support, for example "your grades are very good, keep learning and keep it up"

Most of the parents work as farmers and permanent employees on plantations, so that in supervising their children as students in learning activities is very minimal, but parents always try to guide and are willing to leave their main job in order to be able to accompany their children in learning.

\section{POAC (Planning, Organizing, Actuating, Controlling) at SDN Negla Planning}

Planning for online learning during the covid-19 pandemic at SDN Negla is a design to harmonize the situation, starting with the existence of various things and considerations then the principal of all school stakeholders holds a meeting to find a strategy that is suitable by considering the situation and conditions, then an online learning plan is made at SDN Negla. The agreed learning media is 
Wathsaap Group, because it is considered easier in application and also generally has and masters the application. Activities carried out by teachers during learning during the COVID-19 pandemic include: (a). reducing learning hours; (b). determine the subjects that are considered essential; (c). assigning teachers to be in charge of each class. Judging from the type of educational planning, the online learning policy during the pandemic carried out by SDN Negla is a type of education of planning which according to its use is single use education of planning, which means education planning for one time. If the implementation has been completed, then the educational plan is not used again. If education planning is seen from the time frame, this is included in the short range planning of education, namely short-term planning in education. This educational plan was taken and prepared in a hurry and suddenly because of its importance and the time available was very limited, namely during this pandemic. While the need is urgent and sudden, the implementation of which is less than one year which means educational planning for one-time use. If the implementation has been completed, then the educational plan is not used again. If education planning is seen from the time frame, this is included in the short range planning of education, namely short-term planning in education. This educational plan was taken and prepared in a hurry and suddenly because of its importance and the time available was very limited, namely during this pandemic.

While the need is urgent and sudden, the implementation of which is less than one year which means educational planning for one-time use. If the implementation has been completed, then the educational plan is not used again. If education planning is seen from the time frame, this is included in the short range planning of education, namely short-term planning in education. This educational plan was taken and prepared in a hurry and suddenly because of its importance and the time available was very limited, namely during this pandemic. While the need is urgent and sudden, the implementation of which is less than one year namely short-term planning in education. This educational plan was taken and prepared in a hurry and suddenly because of its importance and the time available was very limited, namely during this pandemic.

\section{Organizing}

learning management also includes organizing. This illustrates that in the process of organizing there are activities in dividing activities according to responsibilities and levels of power and adjusting the flow of cases that occur, for 
example, the case of the child being responsible is the teacher, then to the class teacher or to the new principal to the foundation.

\section{Actuating}

Implementation of learning Related to the implementation of learning implementation at SDN Negla during the current Covid-19 pandemic, among others: Learning is carried out door to door or the teacher visits each student's house to carry out the process of teaching and learning activities. This face-to-face learning activity at SDN Negla was allowed to be carried out because it was included in the Green Zone, but the implementation was carried out in a way where one class was divided into 3 groups. The implementation of learning is carried out door to door where a teacher visits the house which is used as a study group. This door-to-door method is considered more effective than online learning methods that can be applied to elementary school children. One of them is that children do not need an internet network.

\section{Controling}

At least describing the learning program serves to see whether the learning program that has been agreed and distributed to teachers and staff has been implemented in accordance with the SOP or not. This activity is carried out by the principal not aiming to find fault with teachers and administrative staff, but to improve the process in order to improve results.

\section{Factors influencing online learning activities at SDN Negla}

\section{Supporting factors}

Based on the results of the study found 2 supporting factors, namely: First, peer support among teachers and school principals, second motivation, namely teachers can develop their abilities, innovate in making learning strategies, rewards from schools and parents/guardians. First: Support from stakeholders in schools is one of the strengths for the passage of learning, especially for teachers, teachers as the spearhead of the quality of education. For this reason, the professionalism of teachers as learning agents is very important in the midst of this COVID-19 pandemic 


\section{Inhibiting factor}

There are three factors: The first factor is the inability to master information and telecommunications technology, second, the internet network, the third time of implementation and commitment to school stakeholders. These factors become obstacles for teachers, especially in mastering IT, so teachers have to wait and join groups, while the purpose of using IT in online implementation is so that teachers can become more independent. The community in this case the parents of students in this case is very difficult in guiding learning because of the lack of knowledge and experience.

\section{Efforts made in optimizing learning activities during the Covid-19 pandemic at SDN Negla (Kertasari)}

The efforts made are: (1). There is assistance in the form of tablets for 18 students in grades 5 and 6 from the BOS aspiration fund. Although it is very limited, it can at least help the technology-based learning process. (2). The existence of learning innovations, namely POSLAKON and Offline. (3). For teaching materials, anticipating students who do not have technology (Mobile/Internet), we study stories, concepts, we make 2 sheets of A4-sized HVS paper, where we write down the material on sheet 1 and on sheet 2 , namely evaluation. It is considered effective for overcoming quota or internet limitations.

\section{Conclusion}

Online-based learning using electronic media for elementary school students in the WhatsApp use model still needed the role of the teacher as a central role in the instruction process, so that an optimal learning process occurred. In this case, efforts to utilize the WhatsApp application have been carried out well in terms of technology, teacher characteristics, and the characteristics of students' parents. During the distance learning period during the Covid-19 Pandemic at SDN Negla, the researcher argues that the theory of Management includes Planning, Organizing, Actuating and Controling (POAC). Effective means that the target is met according to planning and efficient means that the task is completed in an orderly, organized, and in accordance with the specified time.

\section{Acknowledgement}

We would like to thank the head of the Postgraduate School Study Program at the Indonesian University of Education, an academic supervisor and the Principal 
of SDN Negla (Kertasari) who has given us permission to conduct research on the Implementation of Online Learning Management for Elementary Schools in Rural Areas During the Covid-19 Pandemic. All staff and teachers of SDN Negla (Kertasari) who have been willing to provide data and help obtain the desired results. Thank you to the JMKSP team (Journal of Management, Leadership, and Education Supervision) for providing input in the peer review process.

\section{References}

Africa, S., Development, S. A., Acyl, F., Free, T., Area, T., Summit, T., Committee, T. S., Tfta, T., Community, E. A., African, S., Community, D., Market, C., Africa, S., Africa, S., Union, A., Tfta, T., Fta, G., Summit, T., Secretary, C., ... Summary, E. (2020). Implementasi Pembelajaran Jarak Jauh Selama Pandemi Covid 19 [Implementation of Distance Learning During the Covid 19 Pandemic]. Human Relations, 3(1), 1-8.

Ainun, N. N. (2021). Pandemi dan Ruang Kelas Dunia Maya [Pandemic and Cyberspace Class]. Journal of Educational Technology, Curriculum, Learning and Communication, $1(1), \quad 1$. https://doi.org/10.26858/jetclc.v1i1.18157

Almaiah, M. A., Al-Khasawneh, A., \& Althunibat, A. (2020). Exploring the critical challenges and factors influencing the E-learning system usage during COVID-19 pandemic. Education and Information Technologies, 25(6), 5261-5280. https://doi.org/10.1007/s10639-020-10219-y

Cavenett. (2013). Penerapan Sainstifik Dapat Menigkatkan Motiasi Belajar Siswa [Application of Science Can Increase Student's Learning Motivation]. Journal of Chemical Information and Modeling, 53(9), 1689-1699.

Idhayani, N., Nasir, N., \& Jaya, H. N. (2020). Manajemen Pembelajaran untuk

Menciptakan Suasana Belajar Menyenangkan di Masa New Normal [Learning Management to Create a Fun Learning Atmosphere in the New Normal Period]. Jurnal Obsesi: Jurnal Pendidikan Anak Usia Dini, 5(2), 1556-1566. https://doi.org/10.31004/obsesi.v5i2.911

Indonesia, U.-U. R. (2003). Undang-Undang Republik Indonesia Nomor 20 Tahun 2003 Tentang Sistem Pendidikan Nasional [Law of the Republic of Indonesia Number 20 of 2003 concerning the National Education System] (Vol. 41, Issue 3).

Maria, E., \& Sediyono, E. (2017). Pengembangan Model Manajemen Pembelajaran Berbasis Tik Di Sekolah Dasar [Development of ICT-Based 
Learning Management Model in Elementary School]. Kelola: Jurnal Manajemen Pendidikan, $4(1)$,

59. https://doi.org/10.24246/j.jk.2017.v4.i1.p59-71

Marjuni, A., \& Harun, H. (2019). Penggunaan Multimedia Online Dalam Pembelajaran [Use of Online Multimedia in Learning]. Idaarah: Jurnal Manajemen Pendidikan, 194. https://doi.org/10.24252/idaarah.v3i2.10015

Mulyasidhi, G., \& Haq, M. S. (n.d.). Manajemen Kelas Dalam Kegiatan Pembelajaran Bagi Siswa Sekolah Dasar Pada Masa Pandemi Covid-19 [Class Management in Learning Activities for Elementary School Students During the Covid-19 Pandemic]. Ejournal.Unesa.Ac.Id. https://ejournal.unesa.ac.id/index.php/inspirasi-manajemenpendidikan/article/view/38584

Piccoli, G., Ahmad, R., \& Ives, B. (2001). Web-based virtual learning environments: A research framework and a preliminary assessment of effectiveness in basic it skills training. MIS Quarterly: Management Information Systems, 25(4), 401-426. https://doi.org/10.2307/3250989

Vito, B., \& Krisnani, H. (2015). Kesenjangan Pendidikan Desa Dan Kota [Rural and Urban Education Gap]. Prosiding Penelitian Dan Pengabdian Kepada Masyarakat, 2(2), 247-251. https://doi.org/10.24198/jppm.v2i2.13533 